\title{
Hambatan Pelaksanaan Pembinaan Moral di Lembaga Pemasyarakatan Perempuan Kelas II B Padang
}

\author{
Shandi Resti, Isnarmi \\ Prodi Pendidikan Pancasila dan Kewarganegaraan \\ FIS Universitas Negeri Padang \\ E-mail: shandiresti91@gmail.com
}

\section{ABSTRAK}

Artikel ini bertujuan untuk menganalisis hambatan-hambatan dalam pelaksanaan pembinaan nilai-nilai moral di Lembaga Pemasyarakatan Perempuan Kelas II B Padang. Jenis penelitian ini adalah penelitian kualitatif dengan menggunakan pendekatan deskriptif. Dalam menentukan sampel penelitian, peneliti menggunakan teknik purposive sampling. Informan dalam penelitian ini adalah Kalapas Perempuan Kelas II B Padang, Kasi Binapi Giatja dan warga binaan pemasyarakatan LPP Kelas II B Padang. Teknik pengumpulan data yang digunakan dalam penelitian ini adalah observasi, wawancara dan studi dokumentasi. Teknik analisis data dalam penelitian yaitu pengumpulan data, reduksi data, penyajian data, penarikan kesimpulan dan verifikasi. Hasil penelitian ini menunjukkan hambatan-hambatan dalam pelaksanaan pembinaan moral di LPP Kelas II B Padang, yaitu kurang termotivasinya warga binaan untuk mengikuti kegiatan pembinaan, kurangnya ahli di Bidang Pembinaan Khusus membina moral warga binaan, kurangnya fasilitas ruangan serta terhambatnya kegiatan pembinaan di LPP Kelas II B Padang karena Covid-19.

Kata Kunci: pembinaan, moral, perempuan, LPP

\begin{abstract}
This article aims to analyze the obstacles in the implementation of fostering moral values in the Class II B Women's Penitentiary in Padang. This type of research is a qualitative study using a descriptive approach. In determining the research sample, researchers used purposive sampling technique. The informants in this study were the Head of Class II B Padang Women's Women, the Head of Binapi Giatja, and the Class II B Padang LPP guidance officers. The data collection techniques used in this study were observation, interviews and documentation study. Data analysis techniques in research are data collection, data reduction, data presentation, drawing conclusions and verification. The results of this study indicate the obstacles in the implementation of moral development in LPP Class II B Padang, namely the lack of motivation of the inmates to participate in coaching activities, the lack of experts in the Special Guidance Sector in fostering the morale of the inmates, the lack of room facilities and the inhibition of coaching activities in the Class II LPP B Padang because of Covid-19.
\end{abstract}

Keywords: development moral, woman, LPP 
This work is licensed under the Creative Commons Attribution-ShareAlike 4.0 International License. (C)2021 by author.

\section{PENDAHULUAN}

Salah satu LPP di Indonesia terdapat di Provinsi Sumatera Barat yaitu Lembaga Pemasyarakatan Perempuan Kelas II B Padang yang terletak di Jalan Anak Air, Batipuh Panjang, Kecamatan Koto Tangah, Kota Padang. LPP ini merupakan lembaga di bawah naungan Kementerian Hukum dan Hak Asasi Manusia (KEMENKUMHAM). LPP Kelas II B Padang memiliki 126 orang warga binaan perempuan. Di LPP Kelas II B Padang dilakukan berbagai macam pembinaan untuk warga binaan diantaranya pembinaan kepribadian dan pembinaan kemandirian.

Salah satu bagian dari pembinaan kepribadian adalah pembinaan moral. Pembinaan moral yang dilakukan di Lembaga Pemasyarakatan Perempuan Kelas II B Padang seperti kegiatan apel pagi, kegiatan membaca buku, kegiatan gotong royong dan pembinaan wirid. Dalam pelaksanaannya, ada beberapa hambatan yang dihadapi, diantaranya ialah kurang termotivasinya warga binaan untuk mengikuti kegiatan pembinaan, kurangnya ahli di Bidang Pembinaan Khusus membina moral warga binaan, kurangnya fasilitas ruangan serta terhambatnya kegiatan pembinaan di LPP Kelas II B Padang karena Covid-19. Pembinaan moral ini dilakukan agar tidak ada lagi warga binaan yang keluar masuk tahanan.

Penelitian mengenai pembinaan warga binaan di LPP sudah pernah dilakukan oleh Rotua
Lilis (2014) dengan judul penelitian "Pelaksanaan Pembinaan Narapidana Perempuan di LPP Kelas II B Pekanbaru". Penelitian ini membahas tentang pembinaan warga binaan secara umum. Sementara penelitian ini terfokus pada hambatan dalam pelaksanaan pembinaan nilai moral. Terkait hal itu, peneliti memfokuskan penelitian ini pada hambatanhambatan yang ada dalam pelaksanaan pembinaan moral di Lembaga Pemasyarakatan Perempuan Kelas II B Padang.

\section{METODE PENELITIAN}

Jenis penelitian ini adalah kualitatif dengan metode deskriptif, dengan tujuan untuk menjelaskan pelaksanaan pembinaan moral di Lembaga Pemasyarakatan Perempuan Kelas II B Padang. Informan dalam penelitian ini berjumlah 10 orang diantaranya Kepala Lembaga Pemasyarakatan Perempuan Kelas II B Padang, Kepala Seksi, Kepala Seksi Registrasi dan Klasifikasi, 2 petugas, dan 5 orang warga binaan. Para pegawai LPP Kelas II Padang dipilih berdasarkan keterlibatan mereka dalam pembinaan warga binaan. Sementara warga binaan dipilih untuk mengetahui seberapa besar pengaruh pembinaan terhadap perubahan moral mereka. Teknik sampling yang digunakan pada penelitian ini adalah teknik purposive sampling. Metode pertama yang digunakan ialah observasi dengan mengamati langsung permasalahan mengenai hambatan-hambatan dalam 
pembinaan moral terhadap warga binaan. Metode kedua ialah menggunakan metode wawancara, yakni dengan memberikan sejumlah pertanyaan kepada informan.

\section{HASIL DAN PEMBAHASAN}

Pelaksanaan pembinaan moral terhadap warga binaan perempuan di LPP Kelas II Padang bukanlah suatu hal yang mudah. Hal ini dikarenakan adanya faktor-faktor yang menjadi penghambat dalam pelaksanaan pembinaan itu sendiri, seperti kurang termotivasinya warga binaan untuk mengikuti kegiatan pembinaan, kurangnya ahli di Bidang Pembinaan Khusus membina moral warga binaan, kurangnya fasilitas ruangan di LPP Kelas II B Padang dan terhambatnya kegiatan pembinaan di LPP karena Covid-19.

\section{Kurang termotivasinya warga binaan untuk mengikuti kegiatan pembinaan}

Berdasarkan hasil wawancara dan observasi, warga binaan baru masih mengalami adaptasi terhadap lingkungan disekitar LPP. Warga binaan merasakan perlu beradaptasi dengan kondisi dan suasana di LPP Kelas II B Padang. Oleh karena itu manfaat dari kegiatan pembinaan moral tersebut tidak dirasakan oleh warga binaan yang masih belum rutin mengikuti kegiatan pembinaan di LPP Kelas II B Padang. Pernyataan tersebut juga dibenarkan oleh Ibu Yulidasni, SH sebagai Kasi Binapi Giatja di LPP Kelas II B Padang yang mengatakan bahwa bagi warga binaan yang baru bergabung di LPP Kelas II B Padang memang masih belum bisa beradaptasi sepenuhnya dengan lingkungan LPP. Oleh karena itu ia berharap kepada warga binaan lainnya untuk dapat merangkul sesama agar dapat mengikuti kegiatan pembinaan sebaik mungkin untuk kebaikan mereka juga. Masih ada beberapa warga binaan dengan alasan sakit agar tidak mengikuti kegiatan pembinaan.

\section{Kurangnya Ahli di Bidang Pembinaan Khusus Membina Moral Warga Binaan}

Hambatan terbesar dalam pelaksanaan pembinaan moral di LPP Kelas II B Padang ialah masih belum ada kerjasama dengan pihak luar dalam segi pembinaan khusus moral, kepribadian, watak dan mental. Pembinaan kepribadian tersebut jika dilaksanakan dengan sungguhsungguh maka akan dapat meningkatkan aspek-aspek moral pada anak yaitu moral keagamaan, moral sosial, moral lingkungan dan moral individu (Oktaviana. 2017). Masih belum adanya psikolog atau konselor yang pembinaan moral, kepribadian, watak, dan mental warga binaan pemasyarakatan di LPP.

LPP Kelas II B Padang juga masih kekurangan tenaga ahli tetap di bidang keagamaan. Pihak LPP hanya mendatangkan ustad untuk memberikan ceramah seminggu sekali. Pembinaan moral di LPP Kelas II B Padang dilakukan oleh pihak petugas pembinaan di LPP itu sendiri seperti pembinaan rohani yang meningkatkan nilai-nilai agama para warga binaan, serta pembinaan watak perilaku yang dilakukan dengan mengamalkan nilai agama tersebut. Pembinaan rohani adalah pembinaan yang mmenekankan pada pembinaan karakter, dan nilai-nilai moral (Mannah. 2017).

Berdasarkan teori Van Meter dan Van Horn, variabel sumber daya 
merupakan hal yang sangat memengaruhi keberhasilan pelaksanaan suatu kebijakan (Zulfian. 2014: 36). Dalam hal ini sumber daya yang dimaksud adalah Sumber Daya Manusia. Tujuan dari suatu lembaga akan mudah tercapai apabila SDM di lembaga tersebut memenuhi secara kuantitas dan kualitas. Pihak LPP menitikberatkan pembinaan moral di di bidang pembinaan rohani seperti sholat, mengaji, mendengakan ceramah dan wirid. Hal ini disampaikan oleh Ibu Yulidasni, SH yang mengatakan bahwa LPP Kelas II B Padang menitikberatkan pembinaan nilai-nilai moral untuk warga binaan melalui pembinaan rohani yang di dalamnya dapat mengajarkan nilainilai akan moral kepada warga binaan lewat sholat, mengaji, mendengarkan ceramah dan wirid.

Kurangnya Fasilitas Ruangan di LPP

Kurangnya fasilitas sarana dan prasarana khususnya ruangan menjadi salah satu hambatan dalam pelaksanaan pembinaan. Karena LPP Kelas II B Padang masih menumpang dengan Rutan kelas II B Padang. Selain itu LPP Kelas II B Padang masih dalam tahap pembangunan untuk menambah jumlah ruangan untuk melaksanakan kegiatan pembinaan. Karena kurangnya ruangan di LPP Kelas II B Padang membuat beberapa kegiatan terkadang jadwalnya bentrok dengan kegiatan lain, sehingga pelaksanaan kegiatan pembinaan kurang optimal. Selain itu kondisi kamar hunian yang sempit dan terlalu penuh membuat warga binaan merasa terbatas aktivitasnya. Kurangnya sarana dan prasarana yang dapat berakibat pada hasil dari pembinaan itu sendiri (Erina. 2013).
Terhambatnya Kegiatan Pembinaan di LPP Kelas II B Padang Dampak Covid-19

Kegiatan pembinaan di LPP Kelas II B Padang mengalami hambatan sejak adanya Covid-19. Beberapa kegiatan salah satunya kegiatan rohani (Wirid) yang biasanya dilaksanakan rutin setiap kamis, karena semenjak adanya Covid-19 pembinaan tersebut jadi selang seling dilakukan. Akibatnya, hasil yang diharapkan oleh pihak LPP Kelas II B Padang terhadap pembinaan rohani ini menjadi kurang optimal. Selain itu kunjungan keluarga yang setiap Senin-Kamis diadakan pihak LPP Kelas II B Padang kini tidak lagi menerima kunjungan, hanya boleh mengirim paket kiriman salah satunya dalam bentuk makanan. Hal ini dilakukan untuk memutus rantai penyebaran dari Covid-19.

Ibu Yulidasni juga mengatakan bahwa semenjak adanya Covid-19 ini, pembinaan di LPP Kelas II B Padang yang sebelumnya rutin dilakukan, kini ada beberapa pembinaan yang dikurangi kegiatannya seperti pembinaan wirid yang biasanya dadakan tiap kamis, kini hanya dilakukan sebulan sekali karena mengurangi aktivitas dengan pihak di luar LPP demi menjaga warga binaan dari rantai penyebaran Covid-19 tersebut.

\section{KESIMPULAN}

Berdasarkan temuan penelitian yang peneliti lakukan di LPP Kelas II B Padang terdapat hambatanhambatan dalam pelaksaaan pembinaan moral di LPP tersebut, diantaranya ialah masih kurangnya motivasi warga binaan untuk mengikuti kegiatan pembinaan yang telah diberikan pihak LPP Kelas II B 
Padang. Kurangnya ahli di bidang pembinaan khusus moral menjadi hambatan terbesar dalam pelaksanaan pembinaan moral karena masih belum ada kerjasama dengan pihak luar dalam segi pembinaan khusus moral, kepribadian, watak dan mental. Masih belum adanya psikolog atau konselor yang membina moral, kepribadian, watak, dan mental warga binaan pemasyarakatan di LPP Kelas II B Padang. LPP juga masih kekurangan tenaga ahli tetap di bidang keagamaan. Pihak LPP hanya mendatangkan ustad untuk memberikan ceramah seminggu sekali. Pembinaan moral dilakukan oleh pihak petugas pembinaan di LPP Kelas II B Padang itu sendiri seperti pembinaan rohani yang meningkatkan nilai-nilai agama para warga binaan, serta pembinaan watak perilaku yang dilakukan dengan mengamalkan nilai agama tersebut.

Hambatan lain dalam pelaksanaan pembinaan ialah kurangnya fasilitas ruangan. LPP masih menumpang dengan Rutan kelas II B Padang karena LPP Kelas II B Padang masih dalam tahap pembangunan untuk menambah jumlah ruangan untuk melaksanakan kegiatan pembinaan. Kekurangan ruangan membuat beberapa kegiatan terkadang jadwalnya bentrok dengan kegiatan lain, sehingga pelaksanaan kegiatan pembinaan kurang optimal. Selain itu kondisi kamar hunian yang sempit dan terlalu penuh membuat warga binaan merasa terbatas aktivitasnya. Hambatan dalam pelaksanaan pembinaan di LPP Kelas II B Padang selanjutnya ialah adanya Covid-19, sebab segala jenis kegiatan harus dibatasi demi mencegah penyebaran virus tersebut.

\section{DAFTAR PUSTAKA}

Angkasa. 2010. Over capacity narapidana di lembaga pemasyarakatan, faktor penyebab, implikasi negatif, serta solusi. Jurnal Dinamika Hukum, Vol 10 No 3.

Astuti, Ari. 2011. Pembinaan mental narapidana di Lembaga Pemasyarakatan Wirogunan Yogyakarta. Jurnal Citizenship, Vol 1 No 1.

Dwiatmodjo, Haryanto. 2013. Pelaksanaan pidana dan pembinaan narapidana tindak pidana narkotika (Studi terhadap pembinaan narapidana di Lembaga Pemasyarakatan narkotika klas IIA Yogyakarta). Jurnal Perspektif, Vol 18 No 2.

Hamja, H. 2016. Model Pembinaan Narapidana Berbasis Masyarakat (Community Based Correction). Jurnal Mimbar Hukum, Vol 27 No 3.

Hayati, Mardiyah. 2018. Pembinaan Moral Keagamaan Dan Implikasinya Terhadap Perubahan Perilaku Narapidana Di Blok Melati Lp Kelas II A Kota Mataram. Jurnal Prodi PGMI, Vol.4 No 1.

Isnarmi, Try Wiganda Irfan dan Hasrul. 2019. Pembinaan Moral dan Spiritual pada Warga Binaan (Studi Kasus di Lembaga Pemasyarakatan Kelas IIa Pekanbaru). Jurnal Ilmu-Ilmu Keislaman, Vol. 19 No 1.

Lilis, Rotua. 2014. Pelaksanaan Pembinaan Narapidana Wanita di Lembaga Pemasyarakatan Kelas II B Pekanbaru. JOM Fakultas Hukum. Vol. 1, No. 2. 
Mannah. 2017. Pembinaan Moral dalam Membentuk Karakter. Jurnal Aqidah TA.Vol.III No. 1.

Ningtyas, Erina Suhestia, Abd. Yuli Andi Gani, dan Sukanto. 2014. Pelaksanaan Program Pembinaan Narapidana Pada Lembaga Pemasyarakatan Dalam Rangka Pengembangan Sumber Daya Manusia. Jurnal Administrasi Publik, Vol 1 No 6.

Nur, Lukman dan Mustari. 2017. Pembinaan Moral Narapidana Narkotika Di Lembaga Pemasyarakatan Narkotika Kelas II A Sungguminasa Kabupaten Gowa. TOMALEBBI: Jurnal Pemikiran, Penelitian Hukum, Pendidikan Pancasila dan Kewarganegaraan Vol.4 No 3.

Rina, Suprayitno, dan Salamiah. 2020. Pemberdayaan Napi Perempuan Di Lp Tanjung Gusta Kecamatan Medan Helvetia, Medan, Sumatera Utara. Jurnal Pengabdian masyarakat. Vol. 3 No. 3.
Safa'ah, Yuli dan Anila. 2017. Peranan Bimbingan Konseling Islam Dalam Meningkatkan Moral Narapidana An ak: Studi pada BAPAS Kelas I Semaran.V ol. 12, No 2.

Sanusi, Ahmad. 2019. Evaluasi Pelaksanaan Pembinaan Narapidana di Lembaga Pemasyarakatan Terbuka. Jurnal Ilmu Kebijakan Hukum, Vol 13 No 2.

Teguh. 2015. Pembinaan Narapidana Narkotika dan Obat-Obatan Berbahaya (Narkoba) dalam Perspektif Kehidupan Religiusutas, Jurnal Cakrawala Hukum. Vol 7 No.1.

Zulfian. 2014. Implementasi Kebijakan Program Pendekatan Keluarga Sejahtera dalam pendistribusian alat kontrasepsi di Kabupaten Sintang. Jurnal Administrasi Publik dan Birokrasi. Vol. 1 No. 2 